\title{
Optimizing soil washing remediation of mercury contaminated soil using various washing solutions and solid/liquid ratios
}

\author{
Agus Jatnika Effendi ${ }^{1}$, Vina Lestari $^{2}$, Mohammad Irsyad $^{3}$ \\ ${ }^{1,2}$ Water \& Wastewater Research Group, Faculty of Civil \& Environmental Engineering - ITB, J1. Ganesa no. 10 Bandung 40132 \\ Indonesia \\ ${ }^{3}$ Air \& Solid Waste Management Research Group, Faculty of Civil \& Environmental Engineering - ITB, Jl. Ganesa no. 10 Bandung \\ 40132 Indonesia \\ 1 jatnika@indo.ne.id; ${ }^{2}$ vinalestarird@gmail.com, ${ }^{3}$ mohirsyad@tl.itb.ac.id
}

\begin{abstract}
Most of the artisanal and small-scale gold miners in Indonesia as in the case of those who are in Banten Province, still use the amalgamation process in the gold extraction process. Therefore, mercury contamination could not be avoided. As a result, it was found that the concentration of mercurycontaminated soil in Lebak, Banten Province was detected as high as $136,9 \mathrm{mg} / \mathrm{kg}$. Since the contamination process occurred for a long time, making the formation and mobility of complex mercury in soil increased by time. Soil washing is one remediation technology that can be applied in the recovery of mercury-contaminated soil. This study aims to determine the optimum conditions of the soil washing process: effect of $\mathrm{pH}$, the concentration of washing solutions and ratio of solid/liquid. Furthermore, the value of the distribution coefficient, desorption of mercury in the soil and fractionation of mercury in the soil were also observed. Potassium Iodide was found to be the best washing solution among others used in this study. The optimum condition was obtained at $\mathrm{pH} 2$, the concentration of washing solution at $0.25 \mathrm{M}$ and the solid/liquid ratio of $1: 15$. Under these conditions, mercury desorption efficiency reached $86.9 \%$ with the value of the distribution coefficient of 0.185 . Mercury fractionation analysis in the contaminated soil showed that the mobile $>$ semi-mobile $>$ non-mobile fractions. Potassium iodide was able to desorb at about $84 \%$ of mobile fractions, $97 \%$ of semi-mobile and $25 \%$ non-mobile mercury.
\end{abstract}

Keywords: Soil washing, mercury, desorption, distribution coefficient, fractionation

\section{BACKGROUND}

Artisanal and small-scale gold miners (ASGM) is one of the anthropogenic sources of mercury pollution in the environment. Based on the report of the Ministry of Environment and Forestry, Government of Indonesia there are as many as 850 ASGM points consisting of more than 250,000 miners spread all over Indonesia [1]. According to Ruslan and Khairuddin [2] the process of gold ore beneficiation that carried out by ASGM is called the amalgamation process. Amalgam formation process is carried out in a drum, called the batch amalgamator that using mercury as gold binding agent. Mercury added to drum is reduced at the end of the process due to the processing stage that is allowing mercury to carry away in the wastewater (tailings).

Mercury is a metal that has the potential to be harmful to the environment, especially in areas affected by the gold mining industry. The soil has an important role in the mercury cycle both acting as a medium and source for biota metabolisms, atmosphere and hydrological cycles. Soil can affect mercury forms (species of mercury) through chemical, physical and biological processes, thus affecting solubility, biological accessibility, ecology and toxicological effects of mercury in the environment. Metal mercury in the form of $\mathrm{Hg}^{0}$ is the most non-toxic mercury compound because it is not soluble in water, and it is not bound to animal tissues and cannot be consumed in low-level animals or microbes $[3,4] . \mathrm{Hg}^{0}$ can be oxidized in the atmosphere to inorganic mercury $\left(\mathrm{Hg}^{+2}\right)$ which is found in various forms of salts such as chloride, nitrate or sulfide. $\mathrm{Hg}^{+2}$ is a reactive form of mercury that has a high affinity for animal/plant tissue and can be consumed by microorganisms. Besides $\mathrm{Hg}^{+2}$ functions as a substrate in the process of bacterial methylation under anaerobic conditions, such as in sediments and inundated soils that will form methyl mercury compounds [5].

The fate, pathway and toxicity of mercury in the soil depend on the forms of mercury. Organic mercury species such as methyl mercury have a higher toxicity level and are more easily biologically accumulated when compared to inorganic mercury. This is because organic mercury has large mobility compared to inorganic mercury. The species of mercury in the soil included in the semi-mobile category is a less toxic species of 
mercury. Whereas the non-mobile mercury species are chemically toxic and only mercury sulfide is non-toxic $[6,7]$.

Therefore, it is necessary to remediate mercurycontaminated soil due to tailing disposal of artisanal and small-scale gold mining activities. One remediation technology that can be applied in the recovery of semivolatile or volatile compounds mercury-contaminated soils is by washing the soil or so called a soil washing method. Soil washing is a technique to recover contaminated soil which has several advantages, such as the recovery process has a short time, can be used widely, is economically feasible and can be applied to soil contaminated with semi-volatile or volatile compounds to include mercury $[8,9]$.

\section{METHODOLOGY}

\subsection{SAMPLE PREPARATION}

The composite soil samples were homogenized using the cone quarter method, then using a \pm 200 mesh sieve to separate rocks and large particles [10]. Homogenized soils were then dried at room temperature for 2-3 days [11]. Soil samples were further analysed to determine the initial characteristics of the soil include physical and chemical characteristics. The physical characteristics were soil texture (silt, clay, and sand), moisture content and soil permeability. While the chemical characteristics included soil pH, Cationic Exchange Capacity (CEC), Corganic $\mathrm{C}, \mathrm{N}$ Total, and $\mathrm{P}$ Total as well as metal content. The initial concentration of mercury was $136.9 \mathrm{mg} / \mathrm{kg}$. Data provided in result and discussion part was produced from 2 replicates.

\subsection{SOIL WASHING SOLUTION}

Four (4) washing solutions were used. They were sodium ethylenediaminetetraacetic acid ( $\mathrm{Na}_{2}$ EDTA), potassium chloride $(\mathrm{KCl})$, potassium iodide $(\mathrm{KI})$, and water as control. Each beaker glass contained 20 grams of washing solutions were mixed with water with a ratio of 1:10 $(\mathrm{gr} / \mathrm{mL})$. Batch stirred at a speed of $100 \mathrm{rpm}$ for 3 hours. Then after 3 hours of mixing the sample was taken and centrifuged at a speed of $1000 \mathrm{rpm}$ for 15 minutes. The supernatant was filtered using a vacuum pump filter, to separate the solution from washing and sediment. The filtered supernatant was then destructed before measuring mercury concentration $(\mathrm{Hg})$ using the Atomic Absorption Spectrophotometry (AAS) method.

\subsection{OPTIMUM CONDITIONS DETERMINATION}

A total of 20 grams of contaminated soil were mixed with a $200 \mathrm{ml}$ solution of the best washing solution (KI) at a concentration of $0.2 \mathrm{M}$ with a variation of $\mathrm{pH} 2,3,5$, 7 and 8. The mixture of this soil sample and a solution of KI stirred at a speed of $100 \mathrm{rpm}$ for 3 hours. The mixture was centrifuged at a speed of $1000 \mathrm{rpm}$ for 15 minutes. The supernatant was filtered using a vacuum pump filter and then destructed before measuring mercury concentration (Hg) using the Atomic Absorption Spectrophotometry (AAS) method. Under the optimum $\mathrm{pH}$, the study followed by determining the optimum concentration of KI with variations of $0.1 \mathrm{M}, 0.15 \mathrm{M}, 0.2$ $\mathrm{M}$, and $0.25 \mathrm{M}$ respectively. Finally, after obtaining the optimum $\mathrm{pH}$ and $\mathrm{KI}$ concentration as washing solution, the best ratio of solid/liquid ratio at 1:10, 1: 12.5, 1:15 and 1: $17.5(\mathrm{gr} / \mathrm{mL})$ respectively, were determined.

\subsection{DESTRUCTION PROCEDURE}

The determination of total mercury concentration was obtained after going through the destruction process based on the EPA 7471B method of mercury in solid or semisolid waste (manual cold-vapour technique). The subsequent determination of fractionation of mercury speciation followed the EPA 3200 mercury species fractionation and quantification by microwave-assisted extraction or solid-phase extraction.

\subsection{DISTRIBUTION COEFFICIENT \& MASS BALANCE}

Soil washing performances were carried out by determining the effect of solid/liquid ratio, $\mathrm{pH}$ and concentration of potassium iodide washing solution in mercury removal in polluted soil. The removal efficiency was simply determined by the following equation:

$$
\text { Efficiency }(\%)=\frac{(C \text { initial })-(\text { Ceffluent })}{C \text { initial }} \times 100
$$

Furthermore, to find out the distribution coefficient $(\mathrm{Kd})$ was calculated with the equation as follows:

$$
K d=\frac{C_{1}}{C_{5}}
$$

Then the mass balance calculation was carried out, this calculation is intended to estimate the concentration of contaminants in the liquid phase at the end of the process in optimum conditions with the following equation:

$$
C_{f}=\frac{\left(M_{f} C_{i}\right)-\left(C_{1} V_{1}\right)}{M_{f}}
$$

Where $\mathrm{Kd}$ is the distribution coefficient of metal mercury $(\mathrm{Hg}), \mathrm{C}_{1}$ is the concentration of $\mathrm{Hg}$ in the liquid phase (washwater) and $\mathrm{C}_{\mathrm{s}}$ is the concentration of $\mathrm{Hg}$ in the solid phase or in the soil, $\mathrm{C}_{\mathrm{f}}$ is the final mercury concentration after washing process, $\mathrm{M}_{\mathrm{f}}$ is the soil mass and $V_{1}$ is the volume of washing solution.

\section{RESULTS AND DISCUSSION}

\subsection{INITIAL CHARACTERISTICS OF SOIL}

Table 1 indicated the physical and chemical properties of soil sample. Soil distribution used consists of $85 \%$ silt, $12.7 \%$ fine sand and $2.2 \%$ clay with the initial concentration of total $\mathrm{Hg}$ reached $136.9 \mathrm{mg} / \mathrm{kg}$. Since the soil has high content of silt and sand (more than $90 \%$ in total), soil water content was only $2.46 \%$ because the 
soil has low water holding capacity. The $\mathrm{pH}$ of soil sample was high because the soil was found to have high content of Calcite minerals $\left(\mathrm{CaCO}_{3}\right)$. Moreover, it could be seen that the $\mathrm{C}$-organic content was high making it is difficult to desorb mercury from soil due to reaction between mercury with organic compounds.

Table 1. Soil Samples Physical \& Chemical Properties

\begin{tabular}{|c|c|c|c|}
\hline No & Parameter & Result & Unit \\
\hline \multicolumn{4}{|c|}{ Physical Properties } \\
\hline 1 & Water Content & 2.46 & $\%$ \\
\hline 2 & Specific Gravity & 2.68 & \\
\hline \multicolumn{4}{|c|}{ Chemical Properties } \\
\hline 3 & $\mathrm{pH}$ & 10.25 & \\
\hline 4 & Hg Initial & 136.9 & $\mathrm{mg} / \mathrm{kg}$ \\
\hline 5 & C-organic & 0.617 & $\%$ \\
\hline 6 & $\mathrm{~N}$ total & $<0.004$ & $\%$ \\
\hline 7 & P total & 0.031 & $\%$ \\
\hline 8 & CEC & 11.57 & $\mathrm{cmol} / \mathrm{kg}$ \\
\hline 9 & Organic Matter & 1.829 & $\%$ \\
\hline
\end{tabular}

Metal minerals affect the cation exchange capacity (CEC). According to Pansu and Gautheyrou [12] cation exchange capacity is determined by the amount of clay minerals and organic matter present in the soil. The mechanism of mercury adsorption in clays occurs due to the presence of $\mathrm{Ca}^{+2}, \mathrm{Mg}^{+2}, \mathrm{Na}^{+}$, and $\mathrm{K}^{+}$as shown in table 2. Mercury ions can be replaced with monovalent cations at the site exchange.

Table 2. Metals Mineral in Soil Samples

\begin{tabular}{ccccc}
\hline No & Element & $\begin{array}{c}\text { Value } \\
(\mathbf{\%})\end{array}$ & Compound & $\begin{array}{c}\text { Value } \\
(\%)\end{array}$ \\
\hline $\mathbf{1 .}$ & $\mathrm{C}$ & 10.92 & $\mathrm{C}$ & 10.92 \\
$\mathbf{2 .}$ & $\mathrm{O}$ & 42.47 & - & 1.46 \\
$\mathbf{3 .}$ & $\mathrm{Mg}$ & 0.88 & $\mathrm{MgO}$ & 10.11 \\
$\mathbf{4 .}$ & $\mathrm{Al}$ & 5.35 & $\mathrm{Al}_{2} \mathrm{O}_{3}$ & 64.12 \\
$\mathbf{5 .}$ & $\mathrm{Si}$ & 29.97 & $\mathrm{SiO}_{2}$ & 0.17 \\
$\mathbf{6 .}$ & $\mathrm{S}$ & 0.07 & $\mathrm{SO}_{3}$ & - \\
7. & $\mathrm{Cl}$ & - & - & - \\
$\mathbf{8 .}$ & $\mathrm{K}$ & 3.78 & $\mathrm{~K}_{2} \mathrm{O}$ & 4.55 \\
9. & $\mathrm{Ca}$ & 2.06 & $\mathrm{CaO}$ & 2.88 \\
$\mathbf{1 0}$ & $\mathrm{Fe}$ & 4.5 & $\mathrm{FeO}$ & 5.79 \\
$\mathbf{1 1 .}$ & $\mathrm{Hg}$ & - & $\mathrm{HgS}$ & \\
\hline
\end{tabular}

\subsection{INITIAL FRACTIONATION OF MERCURY SPECIES}

In this study, the fractionation process was carried out in stages in determining the total fractionation of organic, inorganic, semi-mobile and non-mobile. Fractionation was determined based on the EPA 3200 procedure on mercury species fractionation and quantification by microwave-assisted extraction, selective solvent extraction and/or solid-phase extraction. The results of initial fractionation before the soil washing process can be seen in Table 3 .

Based on the results of mercury fractionation, it could be seen that extractable mercury < non-extractable mercury. This indicated that the concentration of mercury dissolved in the washing solution was expected to be relatively small and would be dominated by vaporized mercury. Fractionation results were dominated by organic and semi-mobile mercury, which were 41.61 $\mathrm{mg} / \mathrm{kg}$ and $51.71 \mathrm{mg} / \mathrm{kg}$, respectively.

Table 3 Total initial concentration of mercury fraction

\begin{tabular}{clc}
\hline Mercury Fractionation & $\begin{array}{c}\text { Mercury } \\
\text { Concentration } \\
(\mathbf{m g} / \mathbf{k g})\end{array}$ \\
\hline Extractable & Organic & 46.61 \\
mercury & Inorganic & 6.00 \\
\hline Non-extractable & Semi-mobile & 51.71 \\
mercury & Non-mobile & 39.46 \\
\hline
\end{tabular}

\subsection{EFFECT OF THE WASHING SOLUTION ON MERCURY REMOVAL}

Basically, water has the ability as a washing solution because water is a monodentate chelating agent. However, it was found that the removal efficiency of mercury using water alone as washing solution was low. Based on the results of the study of soil washing processes using water could only remove metal mercury at around $15.18 \%$. Hg metal is very strongly bound with organic compounds and sulphides in the soil to form complex compounds that are insoluble. Therefore, chemicals washing solution is required to desorb mercury from the soil. The results showed that the ability of $\mathrm{Na}_{2}$ EDTA, $\mathrm{KCl}$ and $\mathrm{KI}$ in removing mercury from soil at $\mathrm{pH} 2$ was found at around $22.93 \%, 73.94 \%$ and $84.49 \%$ respectively. So, In the case of mercury chelating agents, potassium iodide was more efficient for mobilizing mercury from the soil as shown in figure 1 . According to Wasay, et al. [13] iodide solution is a better chelation agent than EDTA especially in extracting mercury to form complex compounds.

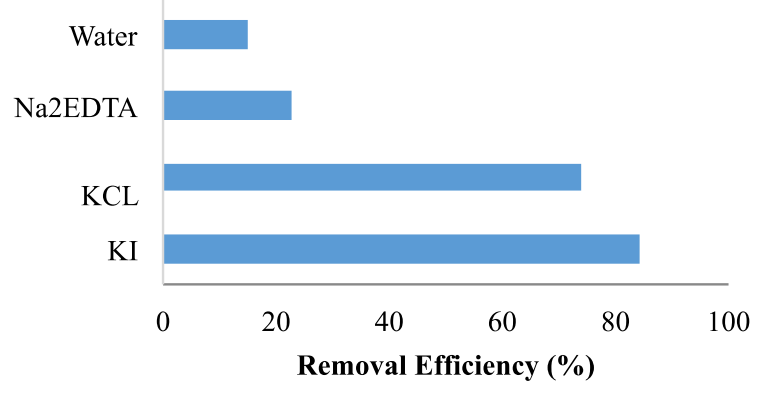

Figure 1. Washing Solutions Removal Effciency

\subsection{PH EFFECT}

Soil washing process by using a solution of potassium iodide at acidic $\mathrm{pH}$ can increase the solubility and desorption of metal ions resulting in the removal of mercury in the soil increases. This was inline with the opinion of Peng, et. al, [14] which stated that extraction especially in the fast extraction process depended on $\mathrm{pH}$ solution where the lower the $\mathrm{pH}$, the faster the extraction process. 


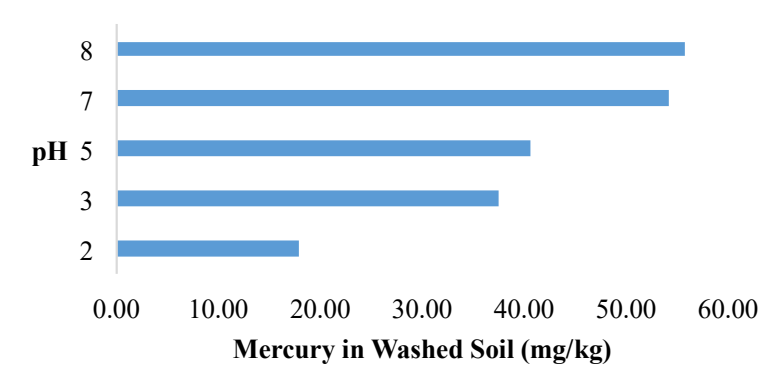

Figure 2. Effect of $\mathrm{pH}$ on Desorption of Mercury using $\mathrm{KI}$ as Washing Solution

Figure 2 above shows the correlation between $\mathrm{pH}$ of washing solution (KI) with mercury retention in soil. It could be seen that the $\mathrm{pH}$ of washing solution affected the ability of the soil to retain mercury significantly. Basically, the lower the $\mathrm{pH}$ value, the greater the desorption process and solubility of mercury from the soil. Potassium iodide (KI) as a chelating agent worked effectively at $\mathrm{pH} 2$ in dissolving mercury to reach removal efficiency up to $85.14 \%$. Mercury concentration in the soil after the soil washing process at $\mathrm{pH} 2$ was found around $20.34 \mathrm{mg} / \mathrm{kg}$. The coefficient of solid/liquid distribution $(\mathrm{Kd})$ is used to estimate the mobility and distribution of elements in the environment [15]. The value of each distribution coefficient can be seen in the following table.

Table 4. Effect of $\mathrm{pH}$ on the distribution coefficient value

\begin{tabular}{|c|c|c|c|}
\hline \multirow[b]{2}{*}{ Sample } & \multicolumn{2}{|c|}{ Mercury Concentration } & \multirow{2}{*}{$\begin{array}{c}\text { Distribution } \\
\text { Coefficient } \\
\text { (L/kg) }\end{array}$} \\
\hline & $\begin{array}{c}\text { Soil } \\
\text { (mg/kg) }\end{array}$ & $\begin{array}{l}\text { Water } \\
(\mathrm{mg} / / \mathrm{L})\end{array}$ & \\
\hline $\mathrm{pH} 2$ & 20.34 & 2.69 & 0.1322 \\
\hline $\mathrm{pH} 3$ & 37.56 & 1.59 & 0.0423 \\
\hline $\mathrm{pH} 5$ & 40.50 & 0.98 & 0.0242 \\
\hline $\mathrm{pH} 7$ & 54.25 & 0.41 & 0.0076 \\
\hline $\mathrm{pH} 8$ & 55.61 & 0.33 & 0.0059 \\
\hline
\end{tabular}

\subsection{SOLID/LIQUID RATIO}

Solid/liquid ratio is a parameter that contributes greatly to the extraction process and removal of contaminants as a whole on contaminated soils, as well affected the amount of residual water produced [16]. Figure 3 indicates the effect of solid/liquid ratio against mercury desorption when KI used as washing solution at $\mathrm{pH}$ 2.0.

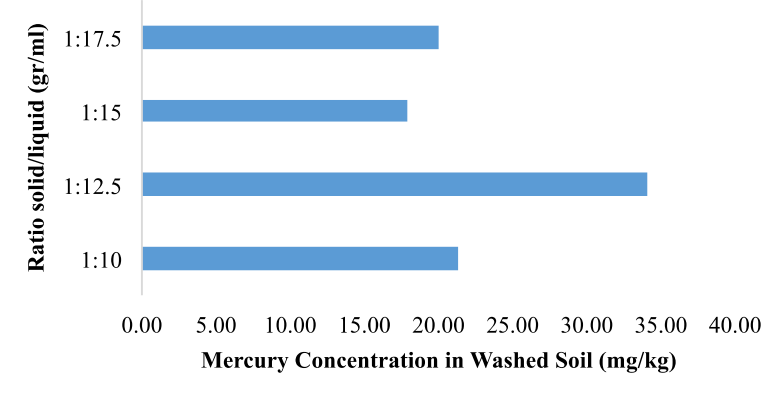

Figure 3. Effect of solid/liquid ratio on desorption of mercury

Based on the results above, it was found that mercury removal using potassium iodide (KI) reached the highest at a solid/liquid ratio of 1:15 ( gram $/ \mathrm{ml})$. The removal efficiency was $86.93 \%$ making mercury concentrations in the soil was $17.89 \mathrm{mg} / \mathrm{kg}$. Wei et. al, [17] stated that the ratio of solid/liquid provides a significant effect on the removal of heavy metals where the low solid/liquid ratio leads to the low ability of washing agent in interacting with heavy metals thereby affecting the efficiency of contaminant removal. Table 5 below shows the effect of solid/liquid ratio to the distribution coefficient $(\mathrm{Kd})$. It could be seen that the highest $\mathrm{Kd}$ was found when the ratio was $1: 15(\mathrm{gr} / \mathrm{mL})$.

Table 5. Effect of solid / liquid ratio on distribution coefficient value

\begin{tabular}{|c|c|c|c|}
\hline \multirow[b]{2}{*}{ Sample } & \multicolumn{2}{|c|}{ Mercury Concentration } & \multirow{2}{*}{$\begin{array}{c}\text { Distribution } \\
\text { Coefficient } \\
\text { (L/kg) }\end{array}$} \\
\hline & $\begin{array}{c}\text { Soil } \\
(\mathrm{mg} / \mathrm{kg})\end{array}$ & $\begin{array}{c}\text { Water } \\
(\mathrm{mg} / / \mathrm{L})\end{array}$ & \\
\hline $1: 10$ & 21.28 & 1.99 & 0.093 \\
\hline $1: 12.5$ & 34.04 & 0.74 & 0.021 \\
\hline $1: 15$ & 17.89 & 2.69 & 0.150 \\
\hline $1: 17.5$ & 20.02 & 2.06 & 0.103 \\
\hline
\end{tabular}

\subsection{WASHING SOLUTION CONCENTRATION}

(KI)

Figure 4 demonstrated that the greater concentration of chelating agents used, the greater the removal efficiency of mercury metal from contaminated soil. Mercury removal efficiency using different concentrations of $\mathrm{KI}$ was found between $68.0 \%-88.8 \%$ at solid/liquid ratio of $1: 15$ and at $\mathrm{pH} 2.0$.

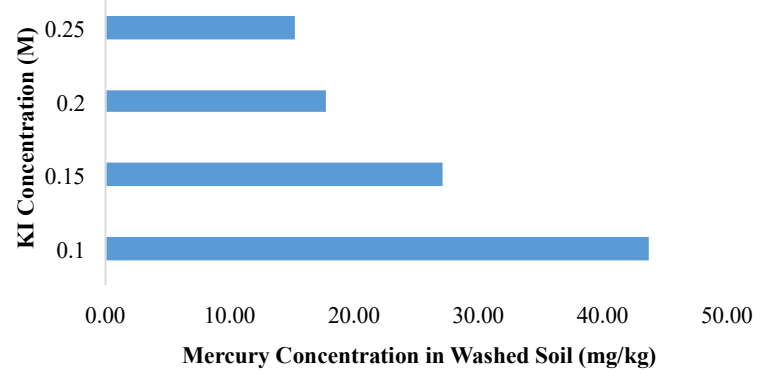

Figure 4. Effect of Washing Solution concentration on Mercury Desorption

At $\mathrm{KI}$ concentration of $0.25 \mathrm{M}$, soil washing process was able to remove mercury from the soil by $88.8 \%$ so that the remaining mercury concentration in the soil was $15.6 \mathrm{mg} / \mathrm{kg}$. The use of high concentrations of KI could reduce the volume of washing solutions required in the soil washing process and form complex compounds with metal mercury because of the presence of excess iodide in the washing solution. Allen, et. al, [18] added that the concentration of chelating agents was influenced by soil characteristics, chelating agent types and types of contaminants. Distribution coefficient was best determined when the KI concentration as washing solution was increased to $0.25 \mathrm{M}$ as shown in Table 6 . 
Table 6. Effect of KI Concentration on distribution coefficient

\begin{tabular}{|c|c|c|c|}
\hline \multirow[b]{2}{*}{ Sample } & \multicolumn{2}{|c|}{ Mercury Concentration } & \multirow{2}{*}{$\begin{array}{c}\text { Distribution } \\
\text { Coefficient } \\
\text { (L/kg) }\end{array}$} \\
\hline & $\begin{array}{c}\text { Soil } \\
(\mathrm{mg} / \mathrm{kg})\end{array}$ & $\begin{array}{l}\text { Water } \\
(\mathrm{mg} / \mathrm{L})\end{array}$ & \\
\hline $0.10 \mathrm{M}$ & 44.45 & 1.66 & 0.037 \\
\hline $0.15 \mathrm{M}$ & 27.47 & 1.82 & 0.066 \\
\hline $0.20 \mathrm{M}$ & 17.89 & 2.69 & 0.150 \\
\hline $0.25 \mathrm{M}$ & 15.60 & 2.88 & 0.185 \\
\hline
\end{tabular}

The $\mathrm{pH}$ value is the most important factor in determining the distribution coefficient $(\mathrm{Kd})$ because the $\mathrm{pH}$ value can increase the solubility of one of the compounds against other compounds that cannot be mixed [19]. Furthermore, the higher the concentration of KI resulted in the greater the distribution of mercury in the solution that is equal to $0.185 \mathrm{~L} / \mathrm{kg}$. According to Gil, et. al, [15] the Kd value is highly dependent on $\mathrm{pH}$, redox conditions, particle size distribution, organic matter content, biological activity, and temperature. However, having examined the distribution coefficient value (d) obtained in this study, it showed that the amount of metal mercury distributed in potassium iodide (KI) solution had low concentration. This was probably due to the mercury contaminated soil used in this study were dominated by volatile compounds so that some of metal mercury vaporized.

\subsection{MERCURY FRACTIONATION OF WASHED SOIL}

Table 7 indicated that the mercury-contaminated soil was dominated by organic mercury fractionation of $46.61 \mathrm{mg} / \mathrm{kg}$ and semi-mobile at $51.71 \mathrm{mg} / \mathrm{kg}$. This was because the sampling site was a former artisanal and small-scale gold mining area that has not been operated since 2016.

Table 7. Mercury Fractionation Concentration Before and After Soil Washing

\begin{tabular}{ccccccc}
\hline & & \multicolumn{5}{c}{$\begin{array}{c}\text { Mercury } \\
\text { Concentration } \\
\text { Mercury } \\
\text { Fractionation }\end{array}$} \\
\cline { 3 - 7 } & & $\begin{array}{c}\text { Before } \\
\text { Soil }\end{array}$ \\
\cline { 3 - 7 } & & \multicolumn{4}{c}{ After Soil Washing } \\
\hline $\begin{array}{c}\text { Washing } \\
\text { Mercury- }\end{array}$ & KI & $\mathrm{KCl}$ & EDTA & $\mathrm{H}_{2} \mathrm{O}$ \\
\hline $\begin{array}{c}\text { Extractable } \\
\text { Mercury- }\end{array}$ & Inorganic & 6.00 & 0.29 & 3.14 & 20.12 & 10.72 \\
\hline $\begin{array}{c}\text { Non } \\
\text { extractable } \\
\text { mercury }\end{array}$ & $\begin{array}{c}\text { Semi- } \\
\text { mobile } \\
\text { mercury }\end{array}$ & 51.71 & 1.14 & 2.73 & 4.59 & 18.48 \\
\hline $\begin{array}{c}\text { Non } \\
\text { extractable } \\
\text { mercury }\end{array}$ & $\begin{array}{c}\text { Non-mobile } \\
\text { mercury }\end{array}$ & 39.46 & 29.32 & 23.85 & 60.21 & 51.82 \\
\hline
\end{tabular}

Inorganic mercury $\left(\mathrm{Hg}^{+2}\right)$ has been involved in the soil microorganism metabolisms to form organic mercury and other complex compounds. Organic mercury fractionation has a higher toxic level compared to other fractions because it is easily mobilized and can accumulate in organisms [20]. After the soil washing process, KI solution was able to remove organic mercury fraction to $7.9 \mathrm{mg} / \mathrm{kg}$, semi-mobile to $1.14 \mathrm{mg} / \mathrm{kg}$, inorganic at $0.29 \mathrm{mg} / \mathrm{kg}$ and non-mobile fractions to reach $29.32 \mathrm{mg} / \mathrm{kg}$. These results demonstrated that $\mathrm{KI}$ was very suitable to be applied as washing solution in the absorption of mercury in the soil compared to others chelating agents.

Furthermore, based on kinetics model using Lagergren equation, the soil washing process using KI $0.25 \mathrm{M}$ as washing solution at $\mathrm{pH} 2$ and solid/liquid ratio of 1:15 was found to be fit with pseudo-second-order kinetics model and was suitable kinetics model in describing the desorption kinetics of mercury in the soil. This result indicated that the entire mechanism process was dominated by chemical process. This was following the role of potassium iodide (KI) as chelating agents that can form complex compounds with mercury in the desorption process. Vadivalen and Kumar [21] stated that if the process adsorption/desorption follows the pseudo second order kinetics model, for the whole adsorption/desorption process, the chemical mechanism is an adsorption/desorption rate controller that is greater than that of physical adsorption/desorption. Desorption rate under this optimum condition was determined at a rate of $\mathbf{0 . 0 0 2 5} / \mathbf{m i n u t e}$ as shown in the following table.

Table 8. Soil Washing Adsorption and Desorption Rate

\begin{tabular}{ccc}
\hline \multirow{2}{*}{ S/L Ratio } & \multicolumn{2}{c}{ Rate (1/minute) } \\
\cline { 2 - 3 } & $\mathbf{K}_{\text {desorption }}$ & $\mathbf{K}_{\text {adsorption }}$ \\
\hline $1: 10$ & 0.0016 & $2.98510^{-6}$ \\
\hline $1: 12.5$ & 0.0010 & $2.64910^{-6}$ \\
\hline $1: 15$ & 0.0025 & $5.84410^{-6}$ \\
\hline $1: 17.5$ & 0.0008 & $5.80610^{-6}$ \\
\hline
\end{tabular}

Overall, mercury retention in soils is controlled by the chemical composition of the soil (sulphur and organic matter), but the rate of desorption controlled by the physical properties of the soil (particle size) [22].

\section{CONCLUSION}

Based on this study, it can be concluded that potassium iodide (KI) was a suitable washing solution to be applied in the absorption of mercury in the soil. The optimum conditions were determined at $\mathrm{pH}$ of 2 , a concentration of washing solution of $0.25 \mathrm{M}$ and a solid/liquid ratio of $1: 15$. With these optimum conditions, potassium iodide could remove mercury more than $88 \%$ with the distribution coefficient value of $0.185 \mathrm{~L} / \mathrm{kg}$. Contaminated soil was dominated by organic mercury that was equal to $46.61 \mathrm{mg} / \mathrm{kg}$ and semi-mobile mercury fraction of $51.71 \mathrm{mg} / \mathrm{kg}$, inorganic mercury fraction of 6 $\mathrm{mg} / \mathrm{kg}$ and non-mobile mercury fraction of $39.46 \mathrm{mg} / \mathrm{kg}$. Potassium iodide (KI) solution was able to remove mercury of organic fraction to $7.9 \mathrm{mg} / \mathrm{kg}$, semi-mobile fraction to $1.14 \mathrm{mg} / \mathrm{kg}$, inorganic fraction to $0.29 \mathrm{mg} / \mathrm{kg}$ and non-mobile fraction to $29.32 \mathrm{mg} / \mathrm{kg}$. These results demonstrated that potassium iodide was very suitable to be applied in the absorption of mercury in the soil with a desorption rate of $0.0025 /$ minute. 


\section{REFERENCE}

1. I. Hamdi, Penambang Emas Gunakan Merkuri KLHK Jelaskan Bahayanya. Berita Online Tempo, https://bisnis.tempo.co/read/1023199/penambangema s-gunakan-merkuri-klhk-jelaskan-

bahayanya/full\&view $=$ ok. Accessed in 10 February 2019 at 19:28. (2017)

2. Ruslan, Khairuddin, Studi Potensi Pencemaran Lingkungan dari Kegiatan Pertambangan Emas Rakyat Poboya Kota Palu, (2011).

3. G. Dermont, G. Bergeron, Mercier, Richer and Lafleche, Soil Washing for Metal Removal: A Review of Physical/chemical Technologies and Field Applications. Journal of Hazardous Materials 152: 1-31(2008).

4. K.R. Mahbub, K. Kanan, N. Ravi, Mercury Toxicity to Terrestrial Biota, Journal Ecological Indicator 74, 451-462 (2017).

5. F.M.M. Morel, A.M.L. Kraepiel, M. Amyot, The Chemical Cycle and Bioaccumulation of Mercury. Journal Ecol Syst. 29, 543 (1998).

6. B.S. Tjahjono, Penyebaran Merkuri Akibat Usaha Pertambangan Emas di Daerah Sangon Kabupaten Kulon Progo D.I. Yogyakarta, (2005).

7. Environmental Protection Agency, Strategy to Address Mercury Containing Products. US EPA. https://www.epa.gov/sites/production/files/201510/documents/productsstrategy.pdf. Accessed in 17 April 2019 at 18:59 wib (2014).

8. M. Jang, J.S. Hwang, S.I. Choi, Sequential soil washing techniques using hydrochloric acid and sodium hydroxide for remediating arseniccontaminated soils in abandoned iron-ore mines. Journal Chemosphere 66, 8e17 (2007).

9. C. William, Anderson, Innovative Site Remediation Technology, American of Environmental Engineerings, ISBN 1-883767-03-2. Annapolis MD. America (1993).

10. W. Zhang, H. Hao, T. Fengfang, W. Hong, Q. Rongliang, Influence of EDTA Washing on The Species and Mobility of Heavy Metals Residual in Soils. Journal of Hazardous Materials. School of Environmental Science and Engineering, Sun Yatsen University. China (2009).

11.Z. Zou, R. Qiu, W. Zang, The study of operating variables in soil washing with EDTA, Journal of Environmental Pollution, 157, 229-236 (2009).

12. M. Pansu, J. Gautheyrou, Handbook of Soil Analysis: Mineralogical, Organic and Inorganic Methods, Springer (2006)

13. S.A. Wasay, P. Arnfalk, S. Tokunaga, Remediation of a soil polluted by mercury with acidic potassium iodide, Journal of Hazardous Material, 44(1), 93-102 (1995).

14. J. Peng, Y. Song, P. Yuan, X. Cui, and G. Qiu, The remediation of heavy metals contaminated sediment, Journal of Hazardous Materials 161, 633640 (2009).

15. G.C. Gil, A. Rigol, M. Vidal, New best estimates for radionuclide solid-liquid distribution coefficients in soils. Part 1: radiostrontium and radiocaesium, Journal of Environmental Radioactivity, 100, 690-696 (2009).

16. M. Andrade, S. Prasher, W. Hendershot, Optimizing the Molarity of a EDTA Washing Solution for Saturated-Soil Remediation of Trace Metal Contaminated Soils. Journal Environ Pollut 147, 781-790 (2007).

17. M. Wei, J. Chen, X. Wang, Removal of Arsenic and Cadmium with Sequential Soil Washing Techniques Using Na2EDTA, Oxalic and Phosphoric Acid: Optimazation Condition, Removal Effectiveness and Ecological Risks, Journal Chemosphere, 156, 252-261 (2016).

18. Allen, H, E., Chen, P. Remediation of metal contaminated soil by EDTA. Journal Environ. Prog. 12(4), 284-293 (1993).

19. S. Sheppard, S. Gustav, B. Mikael, G. Sara, Solid/Liquid Partition Coefficients (Kd) and plant/soil concentration ratios (CR) for Selection Soils, tills and Sediments at Forsmark. ISSN 14023091, 1-77 (2011).

20. M. Sharon, B. Gwaltney, Hascheck and Rousseaux's Handbook of Toxicologic Pathology. 3rd, Chapter IV, Vol II, 1315-1347 (2013).

21. V. Vadivelen, V. Kumar, Equilibrium, kinetics, mechanism and process design for the sorption of methylene blue onto rice husk, Journal of Colloid and Interface Science 286, 90-100 (2005).

22. A.R. Teresa, M.D. Christine, V. Carlos, P. Eduarda, Overview and Challenges of Fractionation and Speciation in Soils. Journal Analytical Chemistry 82, 109-117 (2016). 